Коротун О. П. [1; ORCID ID: 0000-0002-5628-8301], ст. викладач кафедри маркетингу

${ }^{1}$ Національний університет водного господарства та природокористування, м. Рівне

\title{
КРИТЕРІЇ ОЦІНЮВАННЯ ЯКОСТІ ТУРИЗМУ УКРАЇНИ
}

У статті, виходячи 3 розуміння поняття «якість», розроблено теоретичний підхід щодо дослідження особливостей терміну «якість туризму». Використовуючи логіку методики оцінки якості туристичних послуг SERVQUAL (фактичний рівень якості обслуговування складає різницю між очікуваннями та сприйняття послуг споживачами), запропоновано інструментарій оцінювання якості туризму на рівні країни. Доведено, що для держави $є$ необхідними дві умови забезпечення якості туризму - на рівні окремих туристичних підприємств $\mathbf{i}$ на рівні всієї туристичної галузі з метою забезпечення конкурентоспроможності на світовому ринку туристичних послуг. На основі структури субіндексів Індексу конкурентоспроможності країн у сфері подорожей та туризму, визначено фактори, котрі безпосередньо впливають на конкурентоспроможність туристичної галузі: суперництво між конкурентами, нові конкуренти, подібні за своїм складом туристичні послуги або туристичні послуги вищого рівня, постійна зміна уподобань споживачів туристичних послуг стосовно характеристики туристичної послуги, зміна загальної ситуації в країні. 3 допомогою складових індексу конкурентоспроможності країн з подорожей та туризму здійснено оцінку якості вітчизняного туризму, який відображає загальну оцінку чинників, що сприяють розвитку туристичного бізнесу в краӥні.

Результати проведеного оцінювання дали змогу зробити узагальнення щодо низького стану показників якості туризму з позицій зацікавлених сторін: споживачів туристичних послуг, бізнесу, інвесторів $\mathbf{i}$ держави. Проведено групування основних проблем у сфері забезпечення якості туризму, зокрема: інституційні (неефективна діяльність органів державної влади у сфері туризму); політичні (політичні кризи, революції, війни); фінансово-економічні (недостатне фінансове забезпечення туристичної галузі країни 3 боку держави, не повною мірою розвинуті фінансові ринки, часті фінансові кризи; високі банківські кредитні ставки, великий податковий тиск на туристичні підприємства тощо). Через визначену проблематику туристична галузь країни не може конкурувати на світовому ринку туристичних послуг i, відповідно, надавати якісні туристичні послуги, здійснювати інноваційну і інвестиційну діяльність у сфері туризму.

Ключові слова: туристична галузь; критерії оцінювання якості; туристичні послуги; споживачі туристичних послуг; індекс 
конкурентоспроможності країн у сфері подорожей і туризму; субіндекс; туристичний профіль.

Нині якість стала необхідним компонентом для розвитку туристичних підприємств, які мають намір ефективно працювати на ринках туристичних послуг усіх рівнів - місцевого, національного або глобального. У світовій практиці існують еталонні моделі забезпечення якості для підприємств туризму і методики впровадження їх в життя.

Якість - це ключовий фактор, який впливає на конкурентоспроможність підприємств туризму. Проте, у туристичній галузі якість, окрім інших компонент, включає турботу про споживача, інновації у наданні туристичних послуг та постійне їх удосконалення. Іншими словами, завдання якості в туризмі полягає не лише у забезпеченні очікування споживачів, але й у намаганні перевершувати їх очікування. Щоб досягти таких результатів у туристичному бізнесі, керівництву необхідно мати чітку політику управління якістю, яка гармонійно переплітається з їх місією. Окрім зацікавленості туристичного бізнесу в якості, існує і зацікавленість державних органів влади, котрі регулюють процеси на ринку туристичних послуг країни, створюють законодавство у сфері туризму, видають ліцензії на здійснення туристичної діяльності і проводять контроль за дотриманням встановлених норм з метою забезпечення захисту прав споживачів туристичних послуг.

Отже, якість - це невід'ємний аспект будь-якого товару або послуги, який визначає загальновизначені державою соціальні стандарти. У нашому дослідженні ми вживаємо поняття «якість туризму» і розуміємо його як комплексний підхід, орієнтований на споживача туристичних послуг, ступеня його задоволеності i розуміння того, наскільки туристичні послуги та продукти відповідають очікуванням і потребам споживачів.

Потрібно відмітити, що «якість туризму» як термін набуває більш ширшого значення, коли мова йде про об'єктивність оцінювання якості. Відмітимо, що якість туризму має різні виміри і вони важко піддаються оцінюванню, зокрема: 3 позиції оцінки задоволеності споживача - він має потреби та очікування стосовно ряду матеріальних та нематеріальних характеристик. В цьому випадку сприйняття якості асоціюється 3 нематеріальними та естетичними компонентами і оцінка буде дуже суб'єктивною, як функція очікувань та сприйняття, які важко відокремити. Але для туристичних підприємств потрібно їх постійно враховувати, щоб зрозуміти процеси якості послуги. 
У світі існує багато дієвих методик з оцінки якості послуг, проте немає комплексних підходів до оцінювання сфери туризму окремої країни.

Проблемам формування підходів до оцінювання якості туристичних підприємств у своїх працях приділили увагу науковці
Н. Бабіна,
М. Біль,
О. Гринькевич,
О. Корольчук,
0. Любіцева, М. Мальська, Д.Ушакова, І.Школа, Л. Черчик та інші. 3 огляду на численні ґрунтовні дослідження якості туризму, єдиної методології оцінки якості туризму для країни не існує.

Мета статті полягає у виборі критеріїв для здійснення оцінювання якості туризму України.

Однією 3 найпоширеніших методик оцінки якості туристичних послуг $€$ SERVQUAL (Service - сервіс і Quality - якість), яка дає змогу менеджменту туристичних підприємств використовувати сучасні інструменти оцінювання якості наданих послуг та формувати стратегії підвищення якості в умовах конкуренції на ринку туристичних послуг i розробляти заходи щодо підвищення якості менеджменту, а також рівня задоволеності клієнтів.

Таким чином, застосування цього методу дає можливість визначити фактичний рівень якості обслуговування як різницю між очікуваннями та сприйняттям послуг споживачами (рис. 1).

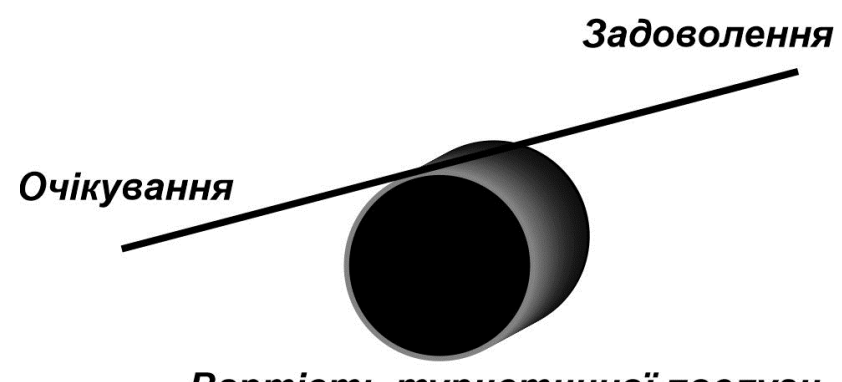

Вартість туристичної послуги

Рис. 1. Оцінювання фактичного рівня якості обслуговування за методикою SERVQUAL (побудовано автором за даними [1])

Алгоритм застосування методу SERVQUAL полягає в оцінці якості туристичної послуги, складовими елементами якої $€$ [1]: відповідність - це ступінь дотримання технічних аспектів, таких як знання та вміння обслуговуючого персоналу, який відповідає встановленим стандартам; здатність персоналу до реагування i готовності - це оперативність, компетентність, ввічливість у вирішенні проблеми клієнтів; надійність - здатність сумлінно надавати стандартизовані послуги; співпереживання - це індивідуальна увага, що приділяється кожному клієнту, яка 
передбачає високий професіоналізм, послідовність або недоліки в управлінні туристичними підприємствами.

Підсумовуючи вищесказане, відмітимо, що якість - це потужний інструмент для підприємств туристичної галузі, який об'єднує у собі три рівнозначні складові: професійну, маркетингову, управлінську.

3 метою проведення комплексної оцінки українського туризму, розглянемо як Всесвітня туристична організація (UNWTO) трактує якість туристичних послуг: «..як результат процесу, що передбачає задоволення будь-якої потреби, запиту чи законного сподівання споживачів щодо товарів та послуг, за прийнятною ціною та за взаємно узгодженими договірними умовами, включаючи неявні основні фактори, такі як гігієна, доступність, справжність та занепокоєння щодо людини та природні екологічні наслідки туристичної діяльності» [2]. Іншими словам, якість, у визначенні Всесвітньої туристичної організації, має перелік таких ознак: не може існувати без поєднання всіх факторів, котрі сприяють створенню досвіду туриста; має бути результатом постійних зусиль керівництва підприємств у сфері туризму, щоб здійснювати постійний контроль на кожному етапі надання туристичної послуги; оцінюється 3 індивідуальної точки зору споживача туристичних послуг, які не $\epsilon$ нематеріальними і, тому є суб'єктивними; відповідає на справедливу ціну як обмін на задоволення основних і життєво важливих потреб людей, які визначаються соціальними та екологічними межами; вимагає уніфікованих критеріїв щодо обов'язкових вимог надання туристичної послуги та здійснення саморегуляції; включає права як для кінцевих, так і для проміжних споживачів; виключає можливість оцінювання якості виключно з точки зору задоволеності споживача туристичних послуг, а потребує включати в оцінку соціальні, економічні та екологічні наслідки діяльності туристичних підприємств.

Таким чином, Всесвітня туристична організація визначає якість як «результат процесу, який передбачає задоволення всіх потреб туристичного продукту та послуг, вимог та очікувань споживача за прийнятною ціною відповідно до взаємно прийнятих умов договору та неявних основних факторів, таких як: безпека, гігієна, доступність, спілкування, інфраструктура, громадські зручності та послуги. Це також включає аспекти етики, прозорості і повага до людського, природного та культурного середовища» [3].

Отже, для держави $є$ необхідними дві умови забезпечення якості туризму - як на рівні окремих туристичних підприємств (збільшення прибутку на основі підвищення якості туристичного обслуговування, підвищення якості праці, створення доступності цін 
на туристичні послуги, постійне покращення якості обслуговування клієнтів), так і на рівні всієї туристичної галузі з метою забезпечення конкурентоспроможності на світовому ринку туристичних послуг. Сформовані у нашому дослідженні висновки дають змогу перейти до головної мети, а саме до здійснення оцінювання якості туризму в Україні.

Відмітимо, що серед головних проблем, які створюють бар'єри для якісної оцінки туристичної галузі країни $€$ недостатність або повна відсутність офіційних статистичних даних щодо видів діяльності (галузей) туризму. Ці проблеми не тільки не дозволяють оцінити якість вітчизняного туризму, а й роблять недостатньо обґрунтованим державне планування і прогнозування, що спричиняє серйозні проблеми у створенні і реалізації стратегії розвитку туризму в Україні.

3 огляду на недостатність або фрагментарність статистичних даних в галузі туризму, у дослідженні використано Індекс конкурентоспроможності країн у сфері подорожей та туризму (The Travel \& Tourism Competitiveness Report, TTCl) [4].

Оскільки якість туризму впливає на конкурентоспроможність туризму у світі, то оцінку якості вітчизняного туризму можна здійснити з допомогою складових індексу конкурентоспроможності країн 3 подорожей та туризму. Цей індекс відображає загальну оцінку чинників, що сприяють розвитку туристичного бізнесу в окремих країнах, проте не визначає привабливість країн як туристичних дестинацій.

Для дослідження використано метод кількісного та якісного порівняння при складанні таблиці на основі індексу конкурентоспроможності країн у сфері подорожей та туризму. Аналізований період - 2012-2019 роки. Проте, варто зазначити, що щорічне рейтингове дослідження проводили з 2007 до 2009 р., 3 2010 р. дослідження проводять один раз у два роки (рис. 2).

Не дивлячись на відносно низькі показники, експерти у сфері туризму зазначають, що 2019 рік продемонстрував для України «...найшвидший темп зростання в субрегіоні, піднявшись на 10 місць, і зайнявши 78 місце в світі. Зокрема, у міру стабілізації та відновлення країни, Україна різко поліпшила ділове середовище (з 124 на 103 місце), безпеку (з 127 на 107 місце), міжнародну відкритість (з 78 на 55 місце) і загальну інфраструктуру (з 79 на 73 місце)» [8]. 


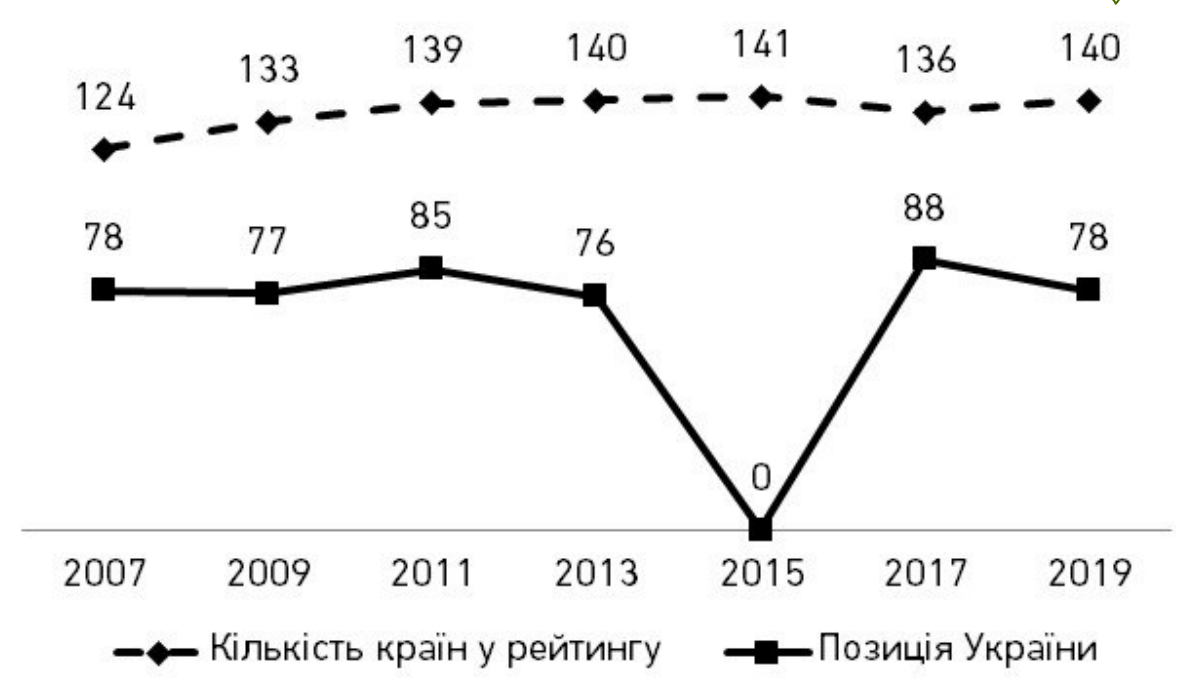

Рис. 2. Динаміка зміни позицій України за Індексом конкурентоспроможності країн у сфері подорожей та туризму за 2007-2019 pp.

Рейтинг ґрунтується приблизно на 80 показниках, які згруповано у 14 складових. Ці складові, у свою чергу, утворюють 3 субіндекси: регуляторне середовище в туристичному секторі; середовище та інфраструктура для бізнесу; людські, культурні і природні ресурси в секторі подорожей і туризму [5].

Структуру індексу конкурентоспроможності у сфері туризму та подорожей подано на рис. 3.

Виходячи зі структури кожного 3 субіндексів продемонстрованого на рис. 3, можна визначити фактори, котрі безпосередньо впливають на конкурентоспроможність туристичної галузі, а саме: суперництво між конкурентами, нові конкуренти, подібні за своїм складом туристичні послуги або туристичні послуги вищого рівня, постійна зміна уподобань споживачів туристичних послуг стосовно характеристики туристичної послуги, зміна загальної ситуації в країні.

3 допомогою структури Індексу конкурентоспроможності країн у сфері подорожей та туризму проведемо аналіз показників кожного субіндексу. Зауважимо, що суттєвою особливістю у рейтингу оцінювання України $€$ те, що за 2015 рік не здійснювались розрахунки показників з причини нестабільної ситуації в Україні. Таким чином, аналізований період для оцінка якості туризму в Україні по субіндексах буде 2013, 2017, 2019 роки. 


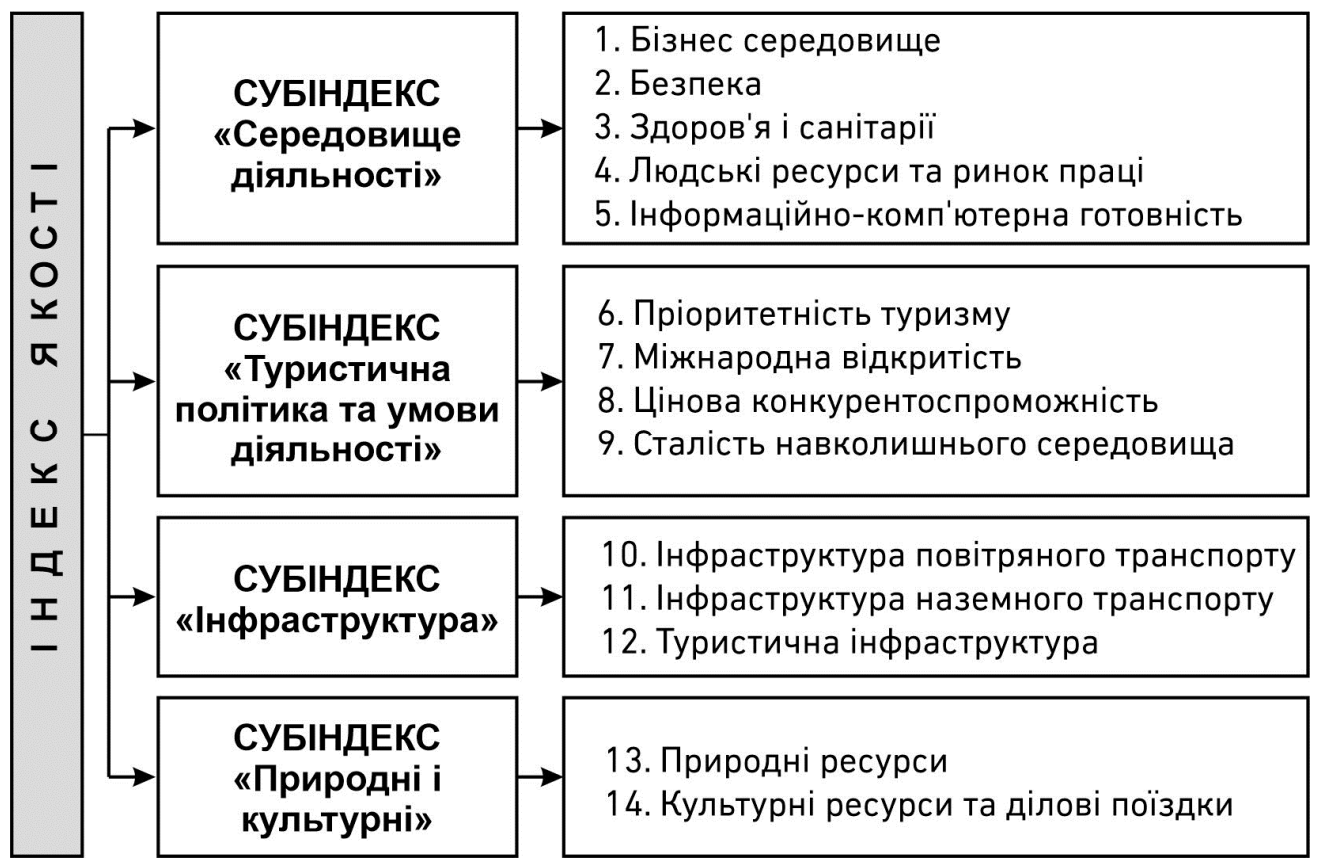

Рис. 3. Структура Індексу конкурентоспроможності країн у сфері подорожей та туризму (сформовано автором на основі [4-5])

3 допомогою структури Індексу конкурентоспроможності країн у сфері подорожей та туризму проведемо аналіз показників кожного субіндексу за 2013, 2017, 2019 рр.

Динаміку показника субіндексу А «Середовище діяльності» Індексу конкурентоспроможності країн у сфері подорожей та туризму за 2013, 2017, 2019 рр. наведено у табл. 1.

Як показує аналіз даних табл. 1, в Україні бізнес-середовище не сприяє розвитку сфери туризму, про що свідчить 124 місце у 2017 році. Проте, за цією складовою у 2019 році ситуація дещо змінилась і становила 103 місце, що дозволила піднятися на 21 пункти. У 2017 році негативний вплив має рівень безпеки в країні - 127 місце, тобто негативно оцінюються такі елементи безпеки як: затрати бізнесу на боротьбу із злочинністю і тероризмом, недостатня довіра до поліції країни, середнє значення загальної кількості терористичних атак і кількості жертв тероризму за 2017 рік суттєво збільшився і збільшилась кількість вбивств на 100 тис населення. Але у 2019 році відбулись позитивні зрушення у політиці держави і за показником «Безпека» рейтинг зріс на 20 пунктів і становив оцінку - 107. Допоки Україна буде перебувати у зоні конфлікту, показник рівня безпеки буде високим. 
Таблиця 1

Динаміка показника субіндексу «Середовище діяльності» Індексу конкурентоспроможності країн у сфері подорожей та туризму за 2013, 2017, 2019 pp.

\begin{tabular}{|l|c|c|c|c|c|c|}
\hline \multirow{2}{*}{ Показники } & \multirow{2}{*}{$\begin{array}{c}\text { Оцінка / } \\
\text { ранг }\end{array}$} & \multicolumn{4}{|c|}{ Роки } & \multicolumn{2}{|c|}{$\begin{array}{c}\text { Зміна оцінки/ } \\
\text { рангу }\end{array}$} \\
\cline { 3 - 7 } & 2013 & 2017 & 2019 & $\begin{array}{c}2019 / \\
2017\end{array}$ & $\begin{array}{c}2019 / \\
2013\end{array}$ \\
\hline \multirow{2}{*}{ Бізнес-середовище } & Ранг & 114 & 124 & 103 & -21 & -11 \\
\cline { 2 - 7 } & Оцінка & 3,9 & 3,7 & 4,1 & 0,4 & 0,2 \\
\hline \multirow{2}{*}{ Безпека } & Ранг & 77 & 127 & 107 & -20 & 30 \\
\cline { 2 - 7 } & Оцінка & 4,7 & 3,5 & 4,8 & 1,3 & 0,1 \\
\hline \multirow{2}{*}{ Здоров'я і санітарія } & Ранг & 8 & 8 & 11 & 3 & 3 \\
\cline { 2 - 7 } & Оцінка & 6,6 & 6,6 & 6,5 & $-0,1$ & $-0,1$ \\
\hline $\begin{array}{l}\text { Людські ресурси та } \\
\text { ринок праці }\end{array}$ & Ранг & 63 & 41 & 48 & 7 & -15 \\
\cline { 2 - 7 } $\begin{array}{l}\text { Інформаційно- } \\
\text { комп'ютерна } \\
\text { готовність }\end{array}$ & Оцінка & 4,9 & 4,9 & 4,8 & $-0,1$ & $-0,1$ \\
\hline $\begin{array}{l}\text { За субіндексом } \\
\text { «Середовище } \\
\text { діяльності» }\end{array}$ & Оцінка & 6,8 & 81 & 78 & -3 & 71,2 \\
\cline { 2 - 7 } & Ранг & 60 & 4,2 & 4,5 & 0,3 & 1,4 \\
\cline { 2 - 7 } & Оцінка & 4,7 & 4,6 & 5,0 & 0,4 & 0,3 \\
\hline
\end{tabular}

Джерело: [4-5]

Динаміка показника субіндексу «Туристична політика та умови діяльності» Індексу конкурентоспроможності країн у сфері подорожей та туризму за 2013, 2017, 2019 рр. подано у табл. 2.

У табл. 2 дані $є$ недостатньо повними, оскільки за 2013 рік вони відсутні. Така відсутність пояснюється змінами, які відбулися впродовж формування Індексу конкурентоспроможності країн у сфері подорожей та туризму, зокрема у зміні його структури.

Тому відмічаємо, що за показником «Пріоритетність туризму» $\epsilon$ незначні позитивні зміни у 2019 році стосовно оцінки 92 проти 90 у 2017 році, але ранг за ці роки залишається незмінним - 3,4. Заслуговують на увагу тенденції у показнику «Міжнародна відкритість», який різко піднісся з 78 до 56 позиції. 
Динаміка показника субіндексу «Туристична політика та умови діяльності» Індексу конкурентоспроможності країн у сфері подорожей та туризму за 2013, 2017, 2019 рр.

\begin{tabular}{|c|c|c|c|c|c|c|}
\hline \multirow{2}{*}{ Показники } & \multirow{2}{*}{$\begin{array}{l}\text { Оцінка / } \\
\text { ранг }\end{array}$} & \multicolumn{3}{|c|}{ Роки } & \multicolumn{2}{|c|}{$\begin{array}{c}\text { Зміна оцінки/ } \\
\text { рангу }\end{array}$} \\
\hline & & 2013 & 2017 & 2019 & $\begin{array}{l}2019 / \\
2017\end{array}$ & $\begin{array}{l}2019 / \\
2013\end{array}$ \\
\hline \multirow{2}{*}{ Пріоритетність туризму } & Ранг & в/д & 90 & 92 & 2 & 92 \\
\hline & Оцінка & в/д & 4,3 & 4,3 & 0 & 4,3 \\
\hline \multirow{2}{*}{ Міжнародна відкритість } & Ранг & в/д & 78 & 56 & -22 & 56 \\
\hline & Оцінка & в/д & 2,9 & 3,7 & 0,8 & 3,7 \\
\hline \multirow{2}{*}{$\begin{array}{l}\text { Цінова } \\
\text { конкурентоспроможність }\end{array}$} & Ранг & 110 & 45 & 19 & -26 & -91 \\
\hline & Оцінка & 4,0 & 5,2 & 5,9 & 0,7 & 1,9 \\
\hline \multirow{2}{*}{$\begin{array}{l}\text { Сталість навколишнього } \\
\text { середовища }\end{array}$} & Ранг & 92 & 97 & 114 & 17 & 22 \\
\hline & Оцінка & 4,3 & 3,9 & 3,9 & 0 & $-0,4$ \\
\hline \multirow{2}{*}{$\begin{array}{l}\text { За субіндексом } \\
\text { «Туристична політика та } \\
\text { умови діяльності» }\end{array}$} & Ранг & 114 & 85 & 70 & -15 & -44 \\
\hline & Оцінка & 3,9 & 4,1 & 4,5 & 0,4 & 0,6 \\
\hline
\end{tabular}

Джерело: [4-5]

Це має логічне пояснення, адже Україна підписала у 2017 році Угоду про асоціацію між Україною та Європейським Союзом [6-7], яка відкрила можливості щодо переходу від партнерства i співробітництва до політичної асоціації та економічної інтеграції.

Також позитивні зміни торкнулись «Цінової конкурентоспроможності», Україна піднялась 345 позиції у 2017 році до 19, а в порівнянні з 2013, цей показник зріс на 91 пункт у 2019 році, що оцінюється дуже позитивно. Загалом ці позитивні зрушення вплинули і на загальний субіндекс «Туристична політика та умови діяльності» і Україна посіла 70 позицію у 2019 році проти 114 позиції у 2013 році, що становило 44 пункти.

Динаміку показника субіндексу «нфраструктура» Індексу конкурентоспроможності країн у сфері подорожей та туризму за 2013, 2017, 2019 рр. подано у табл. 3.

3 табл. 3 видно, що позитивна динаміка спостерігається у показнику «Інфраструктура повітряного транспорту», тобто за аналізований період по цій позиції спостерігаються якісні зміни стосовно: якості авіаційної інфраструктури, стосовно внутрішнього і міжнародного пасажиро-кілометражу та кількості авіакомпаній. У 2019 році показник піднявся на 8 пунктів і посів 71 позицію. 
Таблиця 3

Динаміка показника субіндексу «Інфраструктура» Індексу конкурентоспроможності країн у сфері подорожей та туризму за 2013, 2017, 2019 pp.

\begin{tabular}{|c|c|c|c|c|c|c|}
\hline \multirow{2}{*}{ Показники } & \multirow{2}{*}{$\begin{array}{c}\text { Оцінка / } \\
\text { ранг }\end{array}$} & \multicolumn{3}{|c|}{ Роки } & \multicolumn{2}{|c|}{$\begin{array}{c}\text { Зміна оцінки/ } \\
\text { рангу }\end{array}$} \\
\hline & & 2013 & 2017 & 2019 & $\begin{array}{c}2019 / \\
2017\end{array}$ & $\begin{array}{l}2019 / \\
2013\end{array}$ \\
\hline \multirow{2}{*}{$\begin{array}{l}\text { Інфраструктура } \\
\text { повітряного транспорту }\end{array}$} & Ранг & 78 & 79 & 71 & -8 & -7 \\
\hline & Оцінка & 2,8 & 2,4 & 2,7 & 0,3 & $-0,1$ \\
\hline \multirow{2}{*}{$\begin{array}{l}\text { Інфраструктура наземного } \\
\text { транспорту }\end{array}$} & Ранг & 73 & 81 & 77 & -4 & 4 \\
\hline & Оцінка & 3,5 & 3,0 & 3,1 & 0,1 & $-0,4$ \\
\hline \multirow{2}{*}{ Туристична інфраструктура } & Ранг & 50 & 71 & 65 & -6 & 15 \\
\hline & Оцінка & 4,6 & 4,0 & 4,3 & 0,3 & $-0,3$ \\
\hline \multirow{2}{*}{$\begin{array}{l}\text { За субіндексом } \\
\text { «اнфраструктура» }\end{array}$} & Ранг & 71 & 79 & 73 & -6 & 2 \\
\hline & Оцінка & 3,6 & 3,1 & 3,4 & 0,3 & $-0,2$ \\
\hline
\end{tabular}

Джерело: [4-5]

«Україна - одна з небагатьох країн, що може конструювати всі елементи літака, тому повітряне сполучення та стан авіаційної індустрії демонструють разом із місцевими компаніямиперевізниками стратегічний потенціал у розвитку туризму» [9]. Також позитивні зміни відбулись і по показниках «Інфраструктура наземного транспорту» і «Туристична інфраструктура», що підняло рейтинг за загальним субіндексом «Інфраструктура», а отже, у 2019 році позиція піднялась на 6 пунктів відносно 2017 і становила оцінку 73. Такі результати сприяють покращенню якості туризму в Україні, оскільки інфраструктура для туристичної галузі має виключно важливе значення.

Динаміку показника субіндексу «Природні і культурні ресурси» Індексу конкурентоспроможності країн у сфері подорожей та туризму за 2013, 2017, 2019 рр. розраховано у табл. 4.

Показник «Природні ресурси» у даному оцінюванні $\epsilon$ незадовільним, оскільки рейтинг опускається вниз - 116 місце у 2019 році порівняно із 102 у 2013 році. Це відбувається через зменшення кількості природних об'єктів світової спадщини через «споживацьке» ставлення і недостатній контроль держави до цих об'єктів; поступове зникнення видів флори і фауни; непривабливість природних активів тощо. Трохи кращі позиції демонструє показник «Культурні ресурси та ділові поїздки» за аналізований період у порівнянні з попереднім показником, тобто кількість об'єктів світової спадщини залишилась незмінними; покращилась якість у 
збереженні нематеріальної культурної спадщини (українські звичаї, обряди).

Таблиця 4

Динаміка показника субіндексу «Природні і культурні ресурси» Індексу конкурентоспроможності країн у сфері подорожей та туризму за 2013, 2017, 2019 pp.

\begin{tabular}{|c|c|c|c|c|c|c|}
\hline \multirow{2}{*}{ Показники } & \multirow{2}{*}{$\begin{array}{l}\text { Оцінка } \\
\text { / ранг }\end{array}$} & \multicolumn{3}{|c|}{ Роки } & \multicolumn{2}{|c|}{$\begin{array}{c}\text { Зміна оцінки/ } \\
\text { рангу }\end{array}$} \\
\hline & & 2013 & 2017 & 2019 & $\begin{array}{c}2019 / \\
2017\end{array}$ & $\begin{array}{c}2019 / \\
2013\end{array}$ \\
\hline \multirow{2}{*}{ Природні ресурси } & Ранг & 102 & 115 & 116 & 1 & 14 \\
\hline & Оцінка & 3,0 & 2,3 & 2,2 & $-0,1$ & $-0,8$ \\
\hline \multirow{2}{*}{$\begin{array}{l}\text { Культурні ресурси та } \\
\text { ділові поїздки }\end{array}$} & Ранг & 80 & 51 & 55 & 4 & -25 \\
\hline & Оцінка & 2,1 & 2,1 & 1,9 & $-0,2$ & $-0,2$ \\
\hline \multirow{2}{*}{$\begin{array}{l}\text { За субіндексом } \\
\text { «Природні і культурні } \\
\text { ресурси» }\end{array}$} & Ранг & 99 & 88 & 89 & 1 & -10 \\
\hline & Оцінка & 3,6 & 2,2 & 2,1 & $-0,1$ & $-1,5$ \\
\hline
\end{tabular}

Джерело: [4-5]

Якщо порівнювати стан даної позиції у 2019 році з 2013 роком, то він перемістився з 80 позиції на 55, що на 25 пунктів вище. Ці позитивні зміни вплинули на загальний субіндекс «Природні і культурні ресурси», де позиці змістилась одним пунктом і становила у 2019 році 89 позицію проти 2017 року - 88 позицію.

Провівши оцінювання якості туризму в Україні на основі Індексу конкурентоспроможності країн у сфері подорожей та туризму, можемо оцінити динаміку його чотирьох складових - субіндексів за 2013, 2017, 2019 роки (рис. 4).

3 даних рис. 4 бачимо, що в кожній складовій Індексу конкурентоспроможності країн у сфері подорожей та туризму $\epsilon$ показники, за якими спостерігаються вищі або нижчі оцінки, тобто вони не $є$ сталими. Водночас, підсумковий результат дослідження засвідчує, що якість туризму не $\epsilon$ високою, а передумови для ефективного розвитку туристичної галузі країни використовуються не у повному обсягу. Якщо за базовий взяти період 2019 року, то він має найнижчі показники у порівнянні з попередніми рейтингами. Таке відставання туристичної галузі спричинене цілим рядом проблем, які не дають вітчизняному туризму розвиватися поступово і цілеспрямовано, знижують його потенціал i не сприяють покращенню якості туризму в Україні. Такими типовими проблемами на сьогодні є: несформованість сприятливих умов середовища бізнес сфера, рівень безпеки, інфраструктура інформаційно-комунікаційних технологій; недосконалість державної політики у сфері туризму; 
нерозвинена інфраструктура транспорту і туристична інфраструктура; нераціональне використання, занедбаність і знищення природних ресурсів тощо.

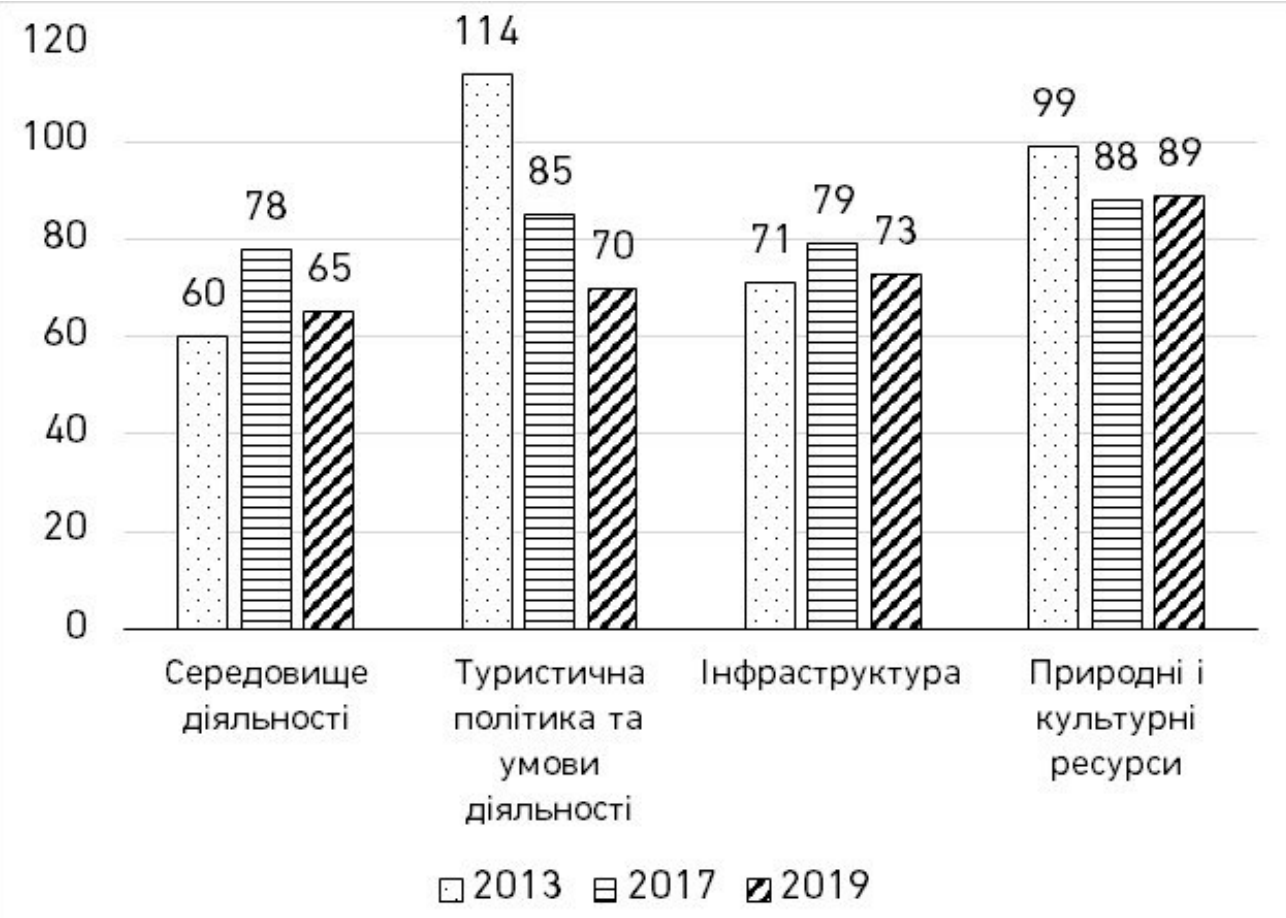

Рис. 4. Динаміка показників субіндексів Індексу конкурентоспроможності країн у сфері подорожей та туризму за 2013, 2017, 2019 рр.*

(побудовано автором на основі [4-5])

Результати проведеного оцінювання дали змогу зробити узагальнення щодо низького стану показників якості туризму 3 позицій зацікавлених сторін: споживачів туристичних послуг, бізнесу, інвесторів і держави.

Основні проблеми у сфері забезпечення якості туризму можна згрупувати у такі блоки: інституційні (неефективна діяльність органів державної влади у сфері туризму); політичні (політичні кризи, революції, війни); фінансово-економічні (недостатнє фінансове забезпечення туристичної галузі країни з боку держави, не повною мірою розвинуті фінансові ринки, часті фінансові кризи; високі банківські кредитні ставки, великий податковий тиск на туристичні підприємства тощо). Через перелічені проблеми туристична галузь країни не може конкурувати на світовому ринку туристичних послуг i, відповідно, надавати якісні туристичні послуги, здійснювати інноваційну і інвестиційну діяльність у сфері туризму. 
Потрібно сказати, що український туризм як такий $\epsilon$ надзвичайно різноманітним і привабливим, проте за весь період незалежності України не було створено належного туристичного профілю країни. Тому загальний профіль туристичної галузі має базуватись на особливостях рис, які для споживачів туристичних послуг дають уявлення про: туристичний продукт і ступінь його диференційованості; кількість і відносні розміри виробників та споживачів; наявність ефекту від масштабу та рентабельність виробництва.

На нашу думку, результатом дослідження оцінки якості туристичної галузі України вважаємо формування туристичного профілю країни, який дасть змогу, на основі звітів Всесвітнього економічного форуму (World Economic Forum) стосовно аналізу Індексу конкурентоспроможності країн у сфері подорожей та туризму у світі, визначити пріоритети стратегічного розвитку туризму з метою побудови підходів до збалансування економічних вигод від підвищення конкурентоздатності туристичної галузі, одночасно ефективно розвиваючи інфраструктуру, цінні природні та культурні цінності і забезпечення високої якості обслуговування туристів. Це i буде предметом подальших наукових досліджень.

1. Parasuraman A., Zeithaml V. A. and Berry L. L. SERVQUAL a Multiple-Item Scale for Measuring Consumer Perceptions of Service Quality. Journal of Retailing. Vol. 64 (1), Spring 1988. 2. World Tourism Organization. UNWTO Quality Support Committee at its sixth meeting, Varadero, Cuba, 9-10 May 2003, UNWTO, Madrid. 3. This is the UNWTO definition of «Quality of a tourism destination» which was endorsed by the 103 UNWTO Executive Council held in Málaga, Spain, in May 2016, and which has been introduced in the present English version. By the time the Spanish version of this publication was released in 2015 this definition could not be included. 4. Travel Tourism Competitiveness Report 2013-2019. URL: http://edclub.com.ua/sites/default/files/files/tourism_3.pdf (дата звернення: 12.11.2020). 5. Бабіна Н. І. Аналіз рейтингу конкурентоспроможності країн у галузі міжнародного туризму. Вісник Миколаївського національного університету імені В.О. Сухомлинського. Миколаїв, 2015. Вип. 3. С. 33-38. 6.Угода про асоціацію між Україною, 3 однієї сторони, та Європейським Союзом, Європейським співтовариством з атомної енергії і їхніми державами-членами, з іншої сторони. Верховна рада України. URL: https://zakon.rada.gov.ua/laws/show/984_011\#Text (дата звернення: 12.11.2020). 7.Про ратифікацію Угоди про асоціацію між Україною, з однієї сторони, та Європейським Союзом, Європейським співтовариством з атомної енергії і їхніми державами-членами, з іншої сторони: Закон України № 1678-VII від 16 вересня 2014 року. URL: https://zakon.rada.gov.ua/laws/show/1678-18\#n2 (дата звернення: 12.11.2020). 8. Україна поліпшила позиції у рейтингу привабливості для туристів. UITT: «УКРАїНА - Подорожі та Туризм». URL: http://www.uitt-kiev.com/ukUA/press/news/3177.aspx (дата звернення: 12.11.2020). 9.Дорожня карта конкурентоспроможного розвитку сфери туризму в Україні: аналітично-дослідна 
організація HDC (Hotel \& Destination Consulting) за підтримки ЄБРP. URL: http://www.ntoukraine.org/assets/files/Tourism-Roadmap-HDC-Presentation-UA.pdf (дата звернення: 12.11.2020).

\section{REFERENCES :}

1. Parasuraman A., Zeithaml V. A. and Berry L. L. SERVQUAL a Multiple-Item Scale for Measuring Consumer Perceptions of Service Quality. Journal of Retailing. Vol. 64 (1), Spring 1988. 2. World Tourism Organization. UNWTO Quality Support Committee at its sixth meeting, Varadero, Cuba, 9-10 May 2003, UNWTO, Madrid. 3. This is the UNWTO definition of «Quality of a tourism destination» which was endorsed by the 103 UNWTO Executive Council held in Málaga, Spain, in May 2016, and which has been introduced in the present English version. By the time the Spanish version of this publication was released in 2015 this definition could not be included. 4. Travel Tourism Competitiveness Report 2013-2019. URL

http://edclub.com.ua/sites/default/files/files/tourism_3.pdf (data zvernennia: 12.11.2020). 5. Babina N. I. Analiz reitynhu konkurentospromozhnosti krain u haluzi mizhnarodnoho turyzmu. Visnyk Mykolaivskoho natsionalnoho universytetu imeni V.O. Sukhomlynskoho. Mykolaiv, 2015. Vyp. 3. S. 33-38. 6. Uhoda pro asotsiatsiiu mizh Ukrainoiu, z odniiei storony, ta Yevropeiskym Soiuzom, Yevropeiskym spivtovarystvom $z$ atomnoi enerhii i yikhnimy derzhavamy-chlenamy, z inshoi storony. Verkhovna rada Ukrainy. URL : https://zakon.rada.gov.ua/laws/show/984_011\#Text (data zvernennia: 12.11.2020). 7. Pro ratyfikatsiiu Uhody pro asotsiatsiiu mizh Ukrainoiu, $z$ odniiei storony, ta Yevropeiskym Soiuzom, Yevropeiskym spivtovarystvom z atomnoi enerhii $\mathrm{i}$ yikhnimy derzhavamy-chlenamy, $z$ inshoi storony : Zakon Ukrainy № 1678-VII vid 16 veresnia 2014 roku. URL: https://zakon.rada.gov.ua/laws/show/1678-18\#n2 (data zvernennia: 12.11.2020). 8. Ukraina polipshyla pozytsii u reitynhu pryvablyvosti dlia turystiv. UITT: «UKRAINA - Podorozhi ta Turyzm». URL: http://www.uitt-kiev.com/ukUA/press/news/3177.aspx (data zvernennia: 12.11.2020). 9. Dorozhnia karta konkurentospromozhnoho rozvytku sfery turyzmu $v$ Ukraini: analitychno-doslidna orhanizatsiia HDC (Hotel \& Destination Consulting) za pidtrymky YeBRR. URL : http://www.ntoukraine.org/assets/files/Tourism-Roadmap-HDC-Presentation-UA.pdf (data zvernennia: 12.11.2020).

Korotun O. P. [1; ORCID ID: 0000-0002-5628-8301], Senior Lecturer of the Department of Marketing

${ }^{1}$ National University of Water Management and Environmental Sciences, Rivne

\section{CRITERIA FOR EVALUATION OF QUALITY OF TOURISM OF UKRAINE}

Based on the understanding of the concept of «quality», the article has
developed a theoretical approach to the study of the characteristics of the
term «quality of tourism». Using the logic of the SERVQUAL methodology for
assessing the quality of tourism services, a toolkit for assessing the quality
of tourism at the country level is proposed. It has been proved that the state
needs two conditions to ensure the quality of tourism at the level of 
individual tourism enterprises and at the level of the entire tourism industry. Based on the structure of the sub-indices of the competitiveness index of countries in travel and tourism, the factors that directly affect the competitiveness of the tourism industry are identified: rivalry between competitors, new competitors, similar in composition, tourism services or top-level tourism services a change in the preferences of consumers of tourism services in relation to the characteristics of a tourist service, a change in the general situation in the country. Using the components of the countries' competitiveness index for travel and tourism, the quality of domestic tourism was assessed, which reflects an overall assessment of the factors contributing to the development of the tourism business in the country.

The results of the assessment made it possible to generalize the relatively low state of tourism quality indicators from the standpoint of stakeholders: consumers of tourism services, business, investors and the state. A grouping of the main problems in the field of ensuring the quality of tourism has been carried out, in particular: institutional (ineffective activity of state authorities in the field of tourism); political (political crises, revolutions, wars) financial and economic (insufficient financial support of the country's tourism industry from the state, financial markets are not fully developed, frequent financial crises; high bank lending rates, large tax pressure travel to tourist enterprises, etc.). Due to the listed problems, the country's tourism industry cannot compete in the world market of tourism services and, accordingly, provide high-quality tourism services, carry out innovation and investment activities in the field of tourism.

Keywords: tourism industry; quality assessment criteria; tourism services; consumers of tourism services; index of countries' competitiveness in travel and tourism; sub-index; tourism profile.

Коротун О. П. ${ }^{[1 ;}$ ORCID ID: 0000-0002-5628-8301], ст. преподаватель кафедры маркетинга

${ }^{1}$ Национальный университет водного хозяйства и природопользования, г. Ровно

\section{КРИТЕРИИ ОЦЕНКИ КАЧЕСТВА ТУРИЗМА УКРАИНЫ}

Исходя из понимания понятия «качество», В статье разработан теоретический подход к исследованию особенностей термина «качество туризма». Используя логику методики оценки качества туристских услуг SERVQUAL, предложено инструментарий оценки качества туризма на уровне страны. Доказано, что государству необходимы два условия для обеспечения качества туризма на уровне отдельных туристических предприятий и на уровне всей туристической индустрии. На основе структуры субиндексов индекса конкурентоспособности стран в сфере 
путешествий и туризма, определены факторы, которые непосредственно влияют на конкурентоспособность туристической отрасли: соперничество между конкурентами, новые конкуренты, подобные по своему составу туристические услуги или туристические услуги высшего уровня, постоянное изменение предпочтений потребителей туристических услуг применительно к характеристике туристической услуги, изменение общей ситуации в стране. С помощью составляющих индекса конкурентоспособности стран по путешествиям и туризму осуществлена оценка качества отечественного туризма, который отражает общую оценку факторов, способствующих развитию туристического бизнеса в стране.

Результаты проведенной оценки позволили сделать обобщения относительно низкого состояния показателей качества туризма с позиций заинтересованных сторон: потребителей туристических услуг, бизнеса, инвесторов и государства. Проведена группировка основных проблем в области обеспечения качества туризма, в частности: институциональные, политические, финансово-экономические. Из-за перечисленных проблем туристская отрасль страны не может конкурировать на мировом рынке туристических услуг и, соответственно, предоставлять качественные туристические услуги, осуществлять инновационную и инвестиционную деятельность в сфере туризма.

Ключевые слова: туристическая отрасль; критерии оценки качества; туристические услуги; потребители туристических услуг; индекс конкурентоспособности стран в сфере путешествий и туризма; субиндекс; туристический профиль. 